\title{
Fish-environment associations in the coastal waters of Andros Island, The Bahamas
}

\author{
Vanessa L. Nero \& Kathleen Sullivan Sealey \\ Coastal Ecology Project, Department of Biology, University of Miami, P.O. Box 249118, Coral Gables, FL \\ 33124,USA; (e-mail: Vanessa.Nero@noaa.gov)
}

Received 11 July $2005 \quad$ Accepted 9 January 2006

Key words: fish-habitat relationships, benthic flora-fauna interactions, detrended canonical correspondence analysis

\section{Synopsis}

We surveyed fish communities and corresponding environmental conditions at three broadly similar coastal sites of eastern Andros Island, The Bahamas over a summer-winter-summer sequence to assess the relationship between detailed environmental features and fish species patterns. Environmental variables included covers of various benthic flora components, benthic flora diversity, floral canopy height, microcrustacean diversity and density, water temperature, extent of destructive land-use and extent of invasion by human-introduced exotic terrestrial plants. Correspondence analysis (CA) indicated that spatial (site) differences in environmental characteristics were greater than temporal (seasonal) differences. Detrended canonical correspondence analysis (DCCA) was used to assess the strength of relationships between the environmental characteristics and the distribution patterns of 25 fish species. Environmental features deemed to be most important in influencing fish species patterns included benthic flora canopy height, extent of invasion by exotic terrestrial plants, cover of Batophora oerstedii, cover of Thalassia testudinum, turf cover, water temperature, micro-crustacean diversity, and micro-crustacean density. Based upon similarities in distribution patterns, fish species formed four clusters which, ultimately, reflected similarities in species' feeding habits and preferences for habitats that likely maximize foraging success. We conclude that fish distribution patterns are related to environmental characteristics, and that anthropogenic coastal activity, by influencing coastal benthic characteristics, may influence the distribution and abundances of fish species in coastal habitats.

\section{Introduction}

Habitat structure and complexity have been considered to be some of the primary factors that influence marine, estuarine, and freshwater fish communities worldwide (Huston 1979, Crowder \& Cooper 1982, Roberts \& Ormond 1987, McClanahan et al. 2000, Able et al. 2002). The role of anthropogenic activities, such as fishing and coastal development, in altering habitat structure and associated fish communities has also been examined in more recent studies (Grigg 1994, Guidetti et al. 2002). Coastal marine habitats represent unique areas exposed to both terrestrial and marine processes, which can each affect habitat quality, structure, and complexity, and, ultimately, fish community patterns.

In recent studies, we determined first that fish communities from different sites in Andros Island, The Bahamas varied with some coarse benthic and coastal characteristics (Nero \& Sealey 2005), and secondly, that detailed benthic floral patterns helped 
to explain observed differences in species and trophic group abundances and biomasses (Nero \& Sealey, in press). In this study, our primary objective was to examine the relationship between an expanded suite of environmental features (including benthic plant and micro-crustacean abundances and diversities, marine vegetation height, water temperature, and extent of exposure to some anthropogenic coastal activities) and observed coastal fish species distributions. We predicted that species distributions would be related to a combination of habitat features, but that benthic plant and benthic micro-crustacean patterns, which directly represent potential food and/or refuge availability (Randall 1967, Kieckbusch et al. 2004, Nagelkerken \& van der Velde 2004), especially for juvenile fishes which inhabit coastal habitats (Mateo \& Tobias 2001), would be most strongly related to fish patterns than would other environmental variables. Because benthic plants and micro-crustacean assemblages can undergo seasonal variation (Lewis 1983, Underwood \& Jernakoff 1984, Sanchez et al. 2003; \& Sealey, unpublished data), sampling over three seasons allowed us to examine if fish patterns responded to seasonal changes in benthic composition.

An underlying goal of this study's primary objective was to elucidate interactions between land and sea in coastal environments. The effects of terrestrial characteristics on coastal marine communities are relatively under-studied, and more studies of interactions at the land-sea interface are needed. In natural, unaltered shorelines, biomass from marine food webs has been shown to support high coastal terrestrial secondary productivity (Polis \& Hurd 1996), but the nature and/or direction of such relationships may change with anthropogenic activities. In this study, our consideration of anthropogenic activities included the extent of invasion by exotic terrestrial plants and the extent of destructive land use. Two humanintroduced invasive plant species, Casuarina equisetifolia (the Australian pine) and Scaevola sericea (Hawaiian beach cabbage), are essentially ubiquitous in the Central Bahamas. These species' shallow root systems, when combined with their ability to out-compete native species, encourage dune destabilization (Hammerton 2001, Sealey et al. 2004) and can result in increased delivery of sediments and nutrients to the marine environment. Destructive land use activities include sand-mining (for construction activities) and dumping of trash, both of which can also directly contribute to dune erosion (Clark 1998), thereby altering natural patterns of sedimentation and nutrient flux between land and sea. These two environmental variables served as proxies for sediment and nutrient transfers to coastal waters, two parameters which, although difficult to characterize, can alter benthic plant assemblages (Umar et al. 1998, Smith et al. 2001) and fish communities (Grigg 1994, Guidetti et al. 2002, Layman et al. 2004). Thus, in accordance with our primary objective, we sought to determine the extent to which fish community patterns were related to terrestrial anthropogenic coastal activities. Our study included sampling at sites which demonstrated varying levels of exposure to anthropogenic activities, and thus would allow for us to detect if and how anthropogenic activities affect coastal fish communities.

The elucidation of habitat preferences and the ability to associate specific habitat qualities with fish species distributions has important ecological and conservation implications, since modern conservation efforts stress the need to conserve entire habitats and ecosystems, not just individual species (Siitonen \& Saaristo 2000, Sergio et al. 2003). Furthermore, because many coastal fish species represent juvenile stages of reef species (Mateo \& Tobias 2001), the ability to identify and preserve adequate habitats can help maintain a healthy supply of adult fishes to coral reefs. The objectives of this study (to identify relationships between specific coastal environmental features and fish species distribution patterns, while examining, in particular, the role of anthropogenic activities in shaping fish distributions) align with current ecological and conservation-based approaches, and were designed to improve our abilities to predict fish community patterns, provide information that can help identify areas most likely in need of conservation, and better understand if and how anthropogenic coastal activity needs to be regulated.

\section{Materials and methods}

\section{Study sites}

Three study sites located along a $16 \mathrm{~km}$ stretch of coastline of eastern North Andros were 
incorporated into this study. Sites, which were located in UTM grid 18R (using datum WGS84), were Blanket Sound (UTM 205031, 2754683), Small Hope Bay (UTM 215488, 2740137), and Staniard Creek Settlement (UTM 208330, 2749097), and are abbreviated as BS, SH, and SC, respectively. All sites were classified as lagoonal patchy soft-bottom algae-seagrass beds (for more detail, see Allee et al. 2000), yet varied in finerscale benthic characteristics (see Appendix A). Each site was sampled in summer (late June through early August) of 2003, winter (January) of 2004, and summer (late June through early August) of 2004, for a total of nine spatio-temporally distinct samples.

\section{Beach seining}

Beach seining, as described in Nero \& Sealey (2005), followed standard seining protocol and began perpendicular to the shoreline. The net used was $20 \mathrm{~m}$ long and $1.5 \mathrm{~m}$ high, with a $1.2 \mathrm{~m}$ wide central pocket. Mesh size was $1 \mathrm{~cm}$ along the wings and $0.4 \mathrm{~cm}$ within the pocket. At each seine 'event', which consisted of four consecutive seines at adjacent stretches of the beach, collected fishes were temporarily held in buckets filled with seawater while species abundances were determined. A total of 48 seine events were completed, which included a minimum of four seine events at each site and season. In order to control for natural tidal and temporal variability (Nero \& Sealey 2005), each site's seine events were distributed among the entire sampling period so as to include as many combinations of different tidal states and times of day as possible. Thus, each site was sampled within the same timeline and schedule of temporal variability. Data corresponding to seines at the same site and season were averaged to produce one final estimate of fish species patterns at each spatio-temporal sample.

\section{Environmental data}

Various environmental variables were measured at each site and season, and included benthic flora diversity, individual covers of different floral components, mean benthic flora canopy height, benthic micro-crustacean diversity (at the order level) and density (number of individuals $/ \mathrm{ml}$ ), water temperature, the extent of destructive land-use, and the extent of exotic terrestrial plants (see Appendix A). Data were collected within the seining area, with benthic flora data collected prior to the beach seining, which could potentially alter natural benthic vegetation patterns.

We used presence-absence surveys to determine flora diversity and point intercept analysis with a 25-point, $1 \mathrm{~m}^{2}$ quadrat along a $60 \mathrm{~m}$ transect line perpendicular to shore to determine proportional covers of Batophora oerstedii, Cladophora spp., Halimeda incrassata, Heterosiphonia gibbesei, Laurencia intricata, Penicillus capitatus, Thalassia testudinum, and benthic turf. Mean canopy height (mm) was estimated by measuring the height of benthic flora (with a hand ruler) at five randomlydetermined points every other meter along the transect line; different random numbers were generated for each quadrat along the transect line. A minimum of four artificial substrate samplers (Myers \& Southgate 1980) were deployed for 3-week periods at each site and season to estimate benthic density and diversity of micro-crustaceans (defined as those crustaceans less than $2 \mathrm{~cm}$ in length). Each sampler was deployed in the general site area, but was placed so as to avoid interference with the seining. Water temperature was measured at each seine event using a hand-held thermometer held just below the surface of the water. Extents of exotic terrestrial plant invasion and destructive land use were determined using the coastal impact ranking methods described in Sealey et al. (2004). As with the fish data, all data representing estimates of the same environmental variable at the same site and season were averaged to obtain one estimate of each environmental variable per spatio-temporal sample.

\section{Data analysis}

Correspondence analysis (CA) was used to assess the similarity in environmental conditions at the nine samples. Interpretation of the CA output was based on scatter-plots of environmental variables and case scores, and numerical output for the first two axes. Detrended Canonical Correspondence Analysis (DCCA) (Ter Braak 1986) was selected to examine the relationships between environmental features and observed fish community patterns; detrending was necessary to address the 'arch effect' (Ter Braak 1986) evident in the 
preliminary Canonical Correspondence Analysis (CCA) plot. Data were square-root transformed to correct for the highly-skewed nature of the data (Ter Braak 1986). The DCCA plot containing site/ season combination scores, fish species scores, and environmental vectors together was too crowded to be interpretable, so, for purposes of clarity, separate plots of each are used. Only those environmental variables with factor loadings whose absolute values were greater than 0.3 , which corresponds to explaining at least $10 \%$ of the variation, were considered as important when interpreting fish-habitat associations (Tabachnick \& Fidell 1996, Chittaro 2004). The weighted average of each species, which indicates the 'center' of a species' distribution along an environmental vector, was used to identify distribution patterns with respect to environmental variables, and to compare distributions of the various species along each environmental variable (see Ter Braak 1986).

Analyses were completed on a subset (25) of the 39 fish species observed throughout the sampling (see Appendix B). Species that were omitted from analyses included very rare species (e.g. species that were collected only once) and schooling atherinids ('silversides'). Atherinids were omitted from the analyses because (i) they were characterized by very erratic distribution and abundance patterns, and (ii) as surface-feeding planktivores (Azevedo Bemvenuti 1990, DeLeon 1999), their occurrences and abundances are probably only minimally connected to the benthos-focused environmental variables investigated in this study.

\section{Results}

The CA scatter-plot based on sample scores (Figure 1) showed a clear pattern of site segregation among the samples. Along axis 1, site BS was positively associated with covers of Heterosiphonia gibbesei, Laurencia intricata, Batophora oerstedii, Thalassia testudinum, and Penicillus capitatus, and increased benthic flora canopy height and negatively associated with covers of turf, Cladophora spp., and Halimeda incrassata (Figure 1, Table 1). Compared to site BS, sites SC and SH demonstrated opposite relationships to these same variables (Figure 1, Table 1). SC and SH samples separated along axis 2, with a seasonal gradient evident along axis 1 . SH samples occupied positive values along axis 2, which corresponded to increased covers of turf, Cladophora spp., Heterosiphonia gibbesei, and Laurencia intricata (see Table 1), while samples from site SC had negative values along axis 2, which corresponded to increased cover of Penicillus capitatus (see Table 1). Eigenvalues for axes 1 and 2 were low (0.023 and 0.017 , respectively). Axis 1 accounted for $40.623 \%$ of the environmental variation among samples, while axis 2 explained an additional $29.076 \%$ of the variation. Overall, BS samples appeared to be characterized by higher covers of erect species of benthic flora, while the SC and $\mathrm{SH}$ samples were characterized by lower covers of erect floral species and higher cover of low-lying floral species.

The CA plot of sample scores based on environmental variables (Figure 1, top) and the DCCA plot of sample scores based on fish species patterns (Figure 2, top) show some similarity with respect to clustering patterns, thereby suggesting that environmental variables and fish community patterns may be related. The strongest similarity is the separation of BS samples from all others. The CA plot (Figure 1) tended to emphasize spatial effects, in that samples from the same site but different seasons were more similar than samples from the same season but different sites. In contrast, the DCCA plot (Figure 2) tended to emphasize strong seasonal effects, in that samples from the same season but different sites were more similar than samples from the same site but different seasons; such results suggest that recruitment events to the area occur at a scale that encompasses the three study sites.

The correlations of DCCA Axis 1 show a contrast between samples with high canopy height, Batophora oerstedii cover, Thalassia testudinum cover, and sea surface temperatures and those samples with a high exotic terrestrial plant cover and micro-crustacean diversity (Table 1). Correlations of DCCA axis 2 show a contrast between samples with high micro-crustacean density and high cover of Thalassia testudinum and samples with high turf cover (Table 1). In conjunction with the species points, the environmental variables included in the analysis accounted for $50.19 \%$ of the variances in the weighted averages of the 25 species. The sum of all eigenvalues was 0.773 . 


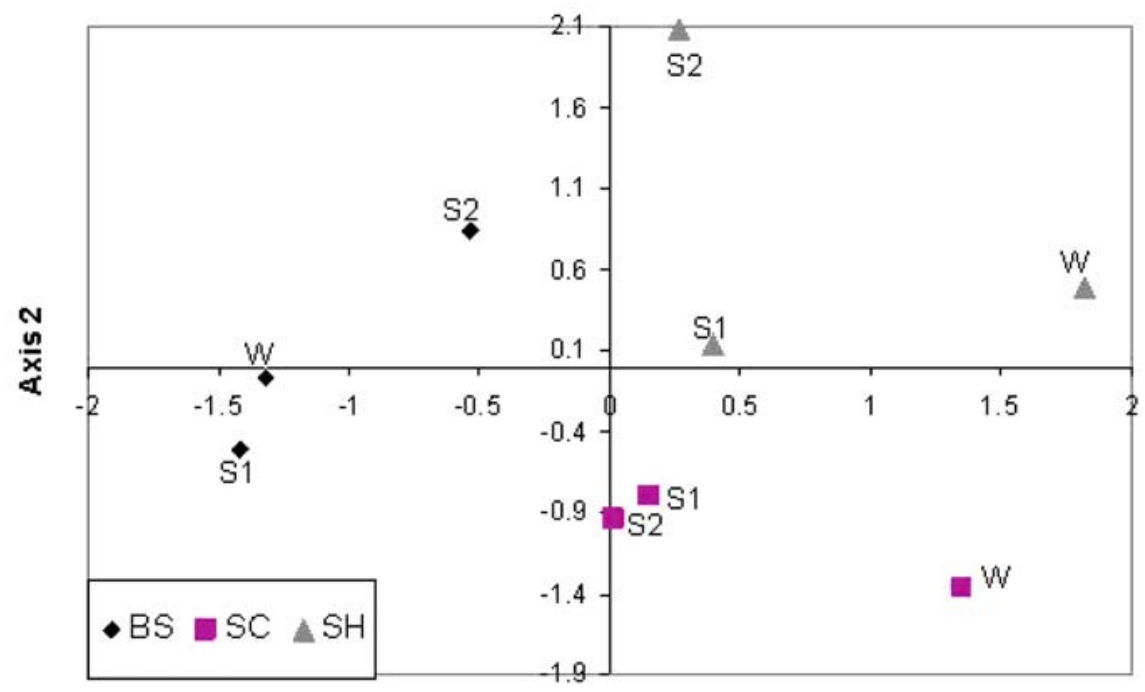

Axis 1

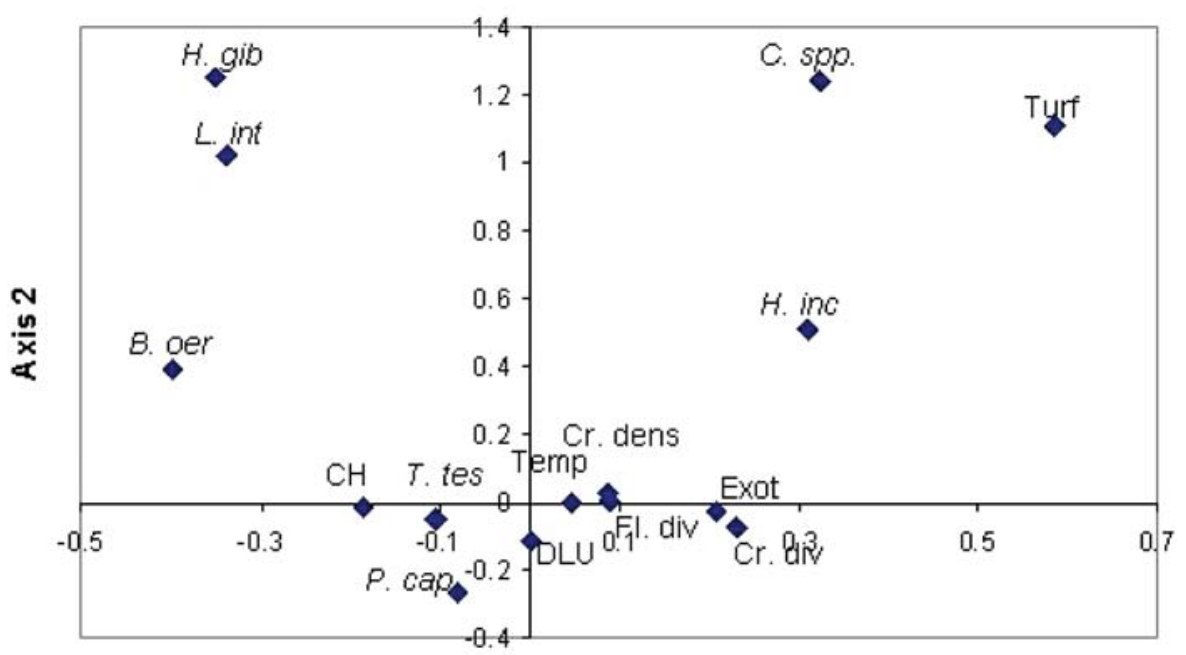

Axis 1

Figure 1. Correspondence analysis (CA) plots of site/season combinations (top) and environmental variables (bottom). For top plot, sample markers represent sites (BS, SC or SH) and labels represent season (S1 = summer 2003, S2 = summer 2004, W = winter 2004). For bottom plot, environmental variables (and abbreviations, when relevant) are: flora diversity (Fl. div), Micro-crustacean diversity (Cr. div), Micro-crustacean density (Cr. dens), Temperature (Temp), Canopy height (CH), Destructive Land Use (DLU), Exotic plants (Exot), Turf, Batophora oerstedii (B. oer), Cladophora spp. (C. spp), Halimeda incrassata (H. inc), Heterosiphonia gibbesei (H. gib), Laurencia intricata (L. int), Penicillus capitatus (P. cap), and Thalassia testudinum (T. tes). Note that in order to clearly show patterns in each plot, different scales are used.

Several species demonstrated similarities in their spatial distributions and relationships to environmental habitat features, as evidenced by the close proximity of species points (Figures 2 and 3). The 25 species were grouped into 4 clusters (see
Figure 2) based upon similarities in their DCCA scores. Each species grouping demonstrated a unique set of relationships with the various environmental variables. A summary of the presence and nature of relationships between the different 
Table 1. CA variable scores, DCCA interset correlations and DCCA bi-plot scores for the 15 environmental variables measured at each site and season.

\begin{tabular}{|c|c|c|c|c|c|c|}
\hline & \multicolumn{2}{|c|}{ CA variable scores } & \multicolumn{2}{|c|}{ Interset correlations } & \multicolumn{2}{|c|}{ Biplot scores } \\
\hline & Axis 1 & Axis 2 & Axis 1 & Axis 2 & Axis 1 & Axis 2 \\
\hline Flora diversity & 0.089 & 0.001 & -0.006 & -0.216 & 0.002 & -0.103 \\
\hline Thalassia testudinum & -0.105 & -0.052 & -0.648 & -0.562 & -0.338 & -0.217 \\
\hline Turf & 0.586 & 1.111 & 0.12 & 0.377 & 0.056 & 0.171 \\
\hline Batophora oerstedii & -0.398 & 0.39 & -0.799 & 0.051 & -0.435 & 0.091 \\
\hline Cladophora spp. & 0.323 & 1.239 & -0.116 & -0.299 & -0.056 & -0.134 \\
\hline Halimeda incrassata & 0.309 & 0.51 & -0.257 & -0.135 & -0.137 & -0.043 \\
\hline Heterosiphonia gibbesei & -0.351 & 1.249 & -0.141 & -0.074 & -0.075 & -0.024 \\
\hline Laurencia intricata & -0.338 & 1.017 & -0.261 & 0.038 & -0.143 & 0.04 \\
\hline Penicillus capitatus & -0.08 & -0.261 & -0.066 & -0.401 & -0.026 & -0.188 \\
\hline Canopy height & -0.187 & -0.011 & -0.881 & -0.286 & -0.472 & -0.064 \\
\hline Temperature & 0.046 & -0.001 & -0.61 & -0.275 & -0.325 & -0.082 \\
\hline Destructive land use & 0 & -0.115 & -0.202 & 0.096 & -0.112 & 0.063 \\
\hline Exotic plants & 0.208 & -0.027 & 0.794 & -0.132 & 0.435 & -0.13 \\
\hline Micro-crustacean diversity & 0.231 & -0.073 & 0.498 & 0.151 & 0.267 & 0.031 \\
\hline Micro-crustacean density & 0.086 & 0.028 & -0.239 & -0.451 & -0.119 & -0.197 \\
\hline
\end{tabular}

fish groupings and each habitat variable is presented in Table 2. As shown in the DCCA bi-plot of fish species and site/season combinations (Figure 3), there is a detectable separation between the fish species characteristic of site BS and those species characteristic of sites SC and $\mathrm{SH}$.

\section{Discussion}

This work suggests that fish community patterns are related to environmental habitat features, as different fish species exhibited clear associations with different sites and environmental features in these coastal lagoonal seagrass/macroalgae beds. Interestingly, our prediction that resource-related features (benthic plants and micro-crustaceans) were more influential than other environmental features was not completely upheld. Given that environmental variables of higher importance are represented by longer arrows (Ter Braak 1986), our DCCA results (refer to Figure 3) indicates that the most important environmental variables, in order of decreasing vector length, were: benthic flora canopy height, extent of invasion by exotic plants, cover of Batophora oerstedii, cover of Thalassia testudinum, water temperature, microcrustacean diversity, and micro-crustacean density. Two of these environmental variables (extent of invasion by exotic plants and temperature) are not directly indicative of food and/or refuge resource availability or quality, suggesting that a wide array of environmental characteristics are important in determining habitat suitability. Because high temperatures decrease oxygen solubility and increase metabolic rate (Helfman et al. 1997), the strong effect of temperature was not completely unexpected. High temperatures can create stressful conditions which may be intolerable to some species, thereby exerting a detectable influence on fish community patterns.

The floral variables determined to be most important (canopy height, cover of Batophora oerstedii and cover of Thalassia testudinum) likely provide a rough approximation of habitat quality and resource potential of an area. Different benthic floral components vary in their structural complexity and morphology, and will therefore vary in their likelihood of providing a resource (e.g. food or shelter) to different fish species. Coral reef studies have been inconclusive with respect to relationships between species abundances and structural complexity (Roberts \& Ormond 1987), but studies of coastal fish communities in the Pacific Ocean (Rotherham \& West 2002) and Indian Ocean (Hyndes et al. 2003) have shown that benthic plants of differing morphologies support unique fish communities; the differences in 

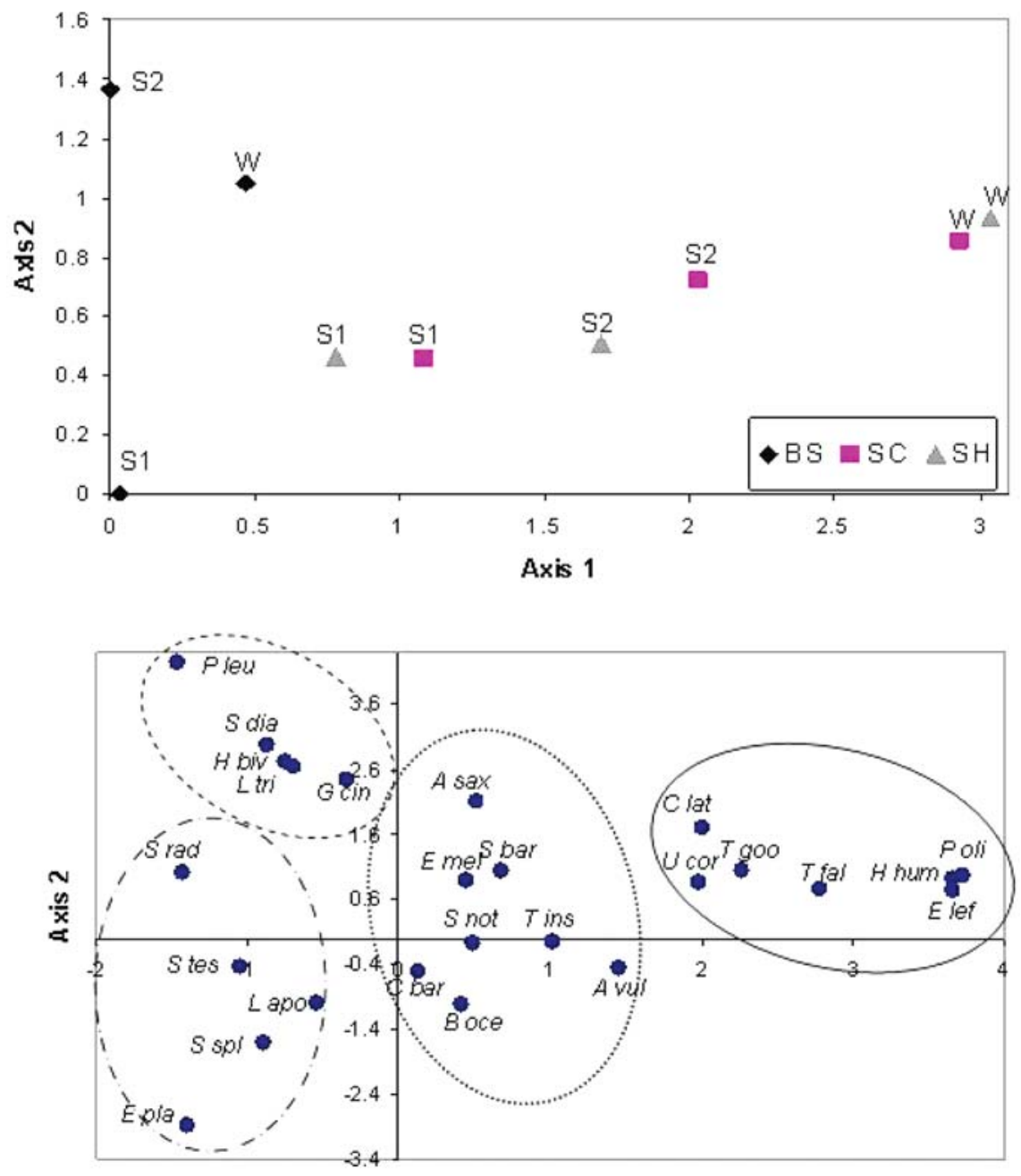

Axis 1

Figure 2. Detrended Canonical Correspondence Analysis (DCCA) plots showing ordination of site/season combinations (top) and fish species (bottom). For top plot, sample markers represent sites (BS, SC or SH) and labels represent season (S1 = summer 2003, S2 = summer 2004, W = winter 2004). For bottom plot, fish species are abbreviated as follows: A sax = Abudefduf saxtalis, $\mathrm{A}$ vul = Albula vulpes, $\mathrm{B}$ oce $=$ Bothus ocellatus, $\mathrm{C}$ bar $=$ Carangoides bartholomaei, $\mathrm{C}$ lat $=$ Caranx latus, $\mathrm{E}$ lef $=$ Eucinostomus lefroyi, $\mathrm{E}$ mel = Eucinostomus melanopterus, $\mathrm{E}$ pla = Eupomacentrus planifrons, $\mathrm{G}$ cin = Gerres cinereus, $\mathrm{H}$ biv $=$ Halichoeres bivittatus, $\mathrm{H}$ hum = Harengula humeralis, $\mathrm{L}$ tri $=$ Lactophrys trigonus, $\mathrm{L}$ apo $=$ Lutjanus apodus, $\mathrm{P}$ oli $=$ Polydactylus oligodon, $\mathrm{P}$ leu = Pomacentrus leucostictus, $\mathrm{S} \mathrm{rad}=$ Sparisoma radians, $\mathrm{S}$ spe $=$ Sphoeroides spengleri, $\mathrm{S}$ tes $=$ Sphoeroides testudineus, $\mathrm{S}$ bar $=$ Sphyraena barracuda, $\mathrm{S}$ dia $=$ Stegastes diancaeus, $\mathrm{S}$ not $=$ Strongylura notata, $\mathrm{T}$ fal $=$ Trachinotus falcatus, $\mathrm{T}$ goo $=$ Trachinotus goodei, $\mathrm{T}$ ins $=$ Trinectes inscriptus, $\mathrm{U}$ cor $=$ Umbrina coroides. Fish species are clustered into groups (enclosed within ovals), as described in the text. Note that in order to clearly show patterns in each plot, different scales are used.

fish communities were attributed to the varying levels of resource availability and predation evasion offered by each plant species. Our study provides evidence that in Bahamian coastal lagoonal habitats dominated by benthic plants, fish patterns are also influenced by the composition of the benthic flora. Benthic seagrasses and macroalgae patterns can exert detectable effects on secondary production, recruitment patterns, direct and indirect food availability, and survival of faunal individuals (Kohn \& Leviten 1976, Gore et al. 1981, Crowder \& Cooper 1982, Marx \& Herrnkind 1985, Eggleston 1995), and we conclude that the differences in benthic flora patterns at the 


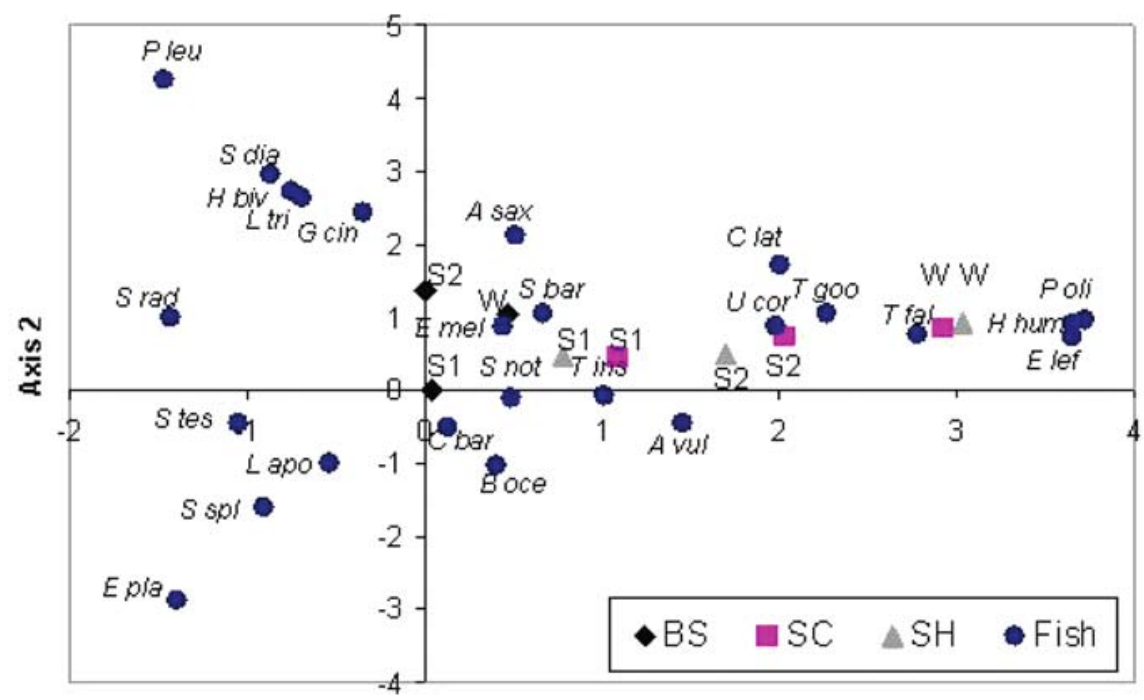

Axis 1

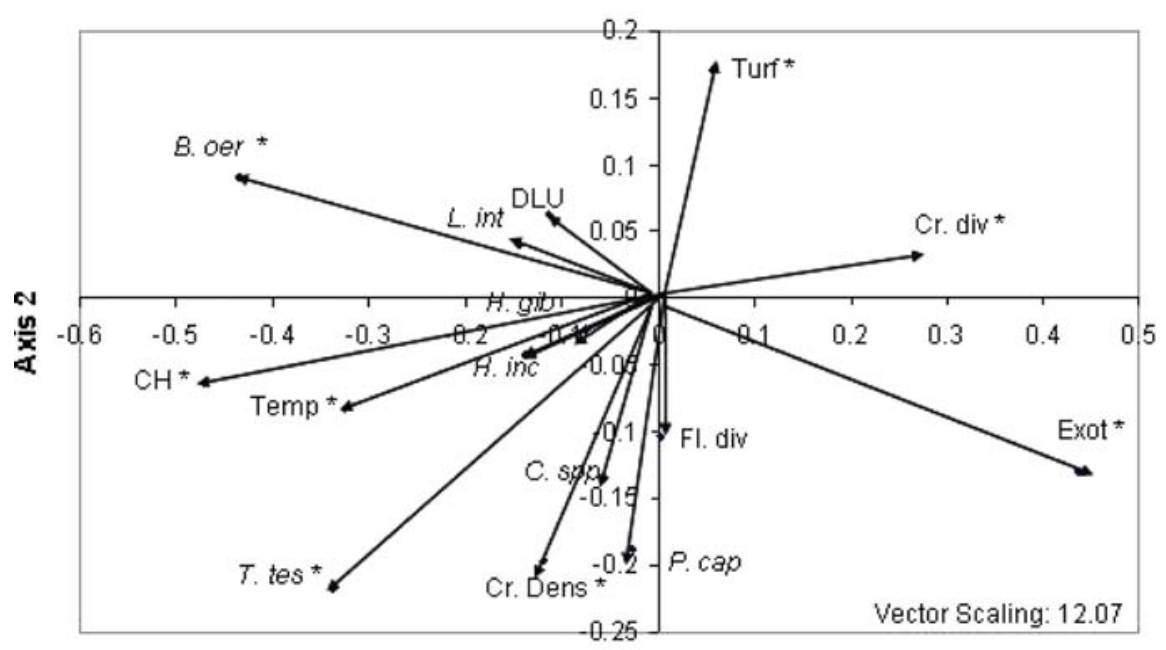

Axis 1

Figure 3. Detrended Canonical Correspondence Analysis (DCCA) bi-plot of site/season combinations and fish species (top) and plot of environmental vectors (bottom). Significant environmental variables (factor loadings with an absolute value greater than 0.3) are labeled with an asterisk. Abbreviations of sites, fish species, and environmental variables follow those of Figures 1 and 2 . Note that in order to clearly show patterns in each plot, different scales are used.

different samples did contribute to the distribution and abundances of coastal fish species. Our finding that fish species patterns were related to benthic plant assemblage patterns suggest that detailed benthic habitat characterization can be used to predict and/or model fish community patterns.

Our DCCA bi-plot (Figure 3) indicated that numerous species demonstrated similar patterns in distributions and habitat preferences. Closer inspection of the species groupings reveals similarities in dietary habits among closely aligned species, and therefore, probably similarities in habitat preferences with respect to ease of obtaining the preferred food items. The group of fishes consisting of Eupomacentrus planifrons, Lutjanus apodus, Sparisoma radians, Sphoeroides spengleri, and Sphoeroides testudineus represent herbivorous and omnivorous species that forage 
Table 2. Summary of DCCA results showing positive $(+)$ and negative $(-)$ correlations between environmental variables and fish species groupings.

\begin{tabular}{|c|c|c|c|c|c|}
\hline & & $\begin{array}{l}\text { Group } 1 \\
\text { Gerres cinereus, } \\
\text { Halichoeres } \\
\text { bivittatus, } \\
\text { Lactophrys } \\
\text { trigonus, } \\
\text { Pomacentrys } \\
\text { leucostictus, } \\
\text { Stegastes } \\
\text { diancaeus }\end{array}$ & $\begin{array}{l}\text { Group } 2 \\
\text { Eupomacentrus } \\
\text { planifrons, } \\
\text { Lutjanus apodus, } \\
\text { Sparisoma radians, } \\
\text { Sphoeroides } \\
\text { splengeri, } \\
\text { Sphoeroides } \\
\text { testudineus }\end{array}$ & $\begin{array}{l}\text { Group } 3 \\
\text { Abedefduf saxtalis, } \\
\text { Albula vulpes, } \\
\text { Bothus ocellatus, } \\
\text { Carangoides, } \\
\text { bartholomaei, } \\
\text { Eucinostomus, } \\
\text { melanopterus, } \\
\text { Sphyraena barracuda, } \\
\text { Strongylura notata, } \\
\text { Trinectes inscriptus }\end{array}$ & $\begin{array}{l}\text { Group } 4 \\
\text { Caranx latus, } \\
\text { Eucinostomus lefroyi, } \\
\text { Harengula humeralis, } \\
\text { Polydactylus oligodon, } \\
\text { Trachinotus falcatus, } \\
\text { Trachinotus goodei, } \\
\text { Ubmbrina coroides }\end{array}$ \\
\hline Abiotic & Temperature & + & + & - & - \\
\hline Anthropogenic & $\begin{array}{l}\text { Destructive land use } \\
\text { Exotic plants }\end{array}$ & $\begin{array}{c}\text { ns } \\
-\end{array}$ & $\begin{array}{c}\text { ns } \\
-\end{array}$ & $\begin{array}{l}\text { ns } \\
-\end{array}$ & $\begin{array}{c}\text { ns } \\
+\end{array}$ \\
\hline Benthic plants & $\begin{array}{l}\text { Batophora oerstedii } \\
\text { Cladophora spp. } \\
\text { Halimeda incrassata } \\
\text { Heterosiphonia gibbesei } \\
\text { Laurencia intricate } \\
\text { Penicillus capitatus } \\
\text { Thalassia testudinum } \\
\text { Turf } \\
\text { Canopy height } \\
\text { Diversity }\end{array}$ & $\begin{array}{l}+ \\
\mathrm{ns} \\
\mathrm{ns} \\
\mathrm{ns} \\
\mathrm{ns} \\
\mathrm{ns} \\
+ \\
+ \\
+ \\
\mathrm{ns}\end{array}$ & $\begin{array}{l}+ \\
\text { ns } \\
\text { ns } \\
\text { ns } \\
\text { ns } \\
\text { ns } \\
+ \\
- \\
+ \\
\text { ns }\end{array}$ & $\begin{array}{l}- \\
\mathrm{ns} \\
\mathrm{ns} \\
\mathrm{ns} \\
\mathrm{ns} \\
\mathrm{ns} \\
- \\
+ \\
- \\
\mathrm{ns}\end{array}$ & $\begin{array}{l}- \\
\mathrm{ns} \\
\mathrm{ns} \\
\mathrm{ns} \\
\mathrm{ns} \\
\mathrm{ns} \\
- \\
+ \\
- \\
\mathrm{ns}\end{array}$ \\
\hline Micro-crustaceans & $\begin{array}{l}\text { Diversity } \\
\text { Density }\end{array}$ & $\begin{array}{l}- \\
-\end{array}$ & $\begin{array}{l}- \\
+\end{array}$ & $\begin{array}{l}+ \\
-\end{array}$ & $\begin{array}{l}+ \\
-\end{array}$ \\
\hline
\end{tabular}

Only correlations considered important for interpretation (i.e. those that account for at least $10 \%$ of the variance between environmental and fish species variables) are presented as positive or negative relationships; those which explained less than $10 \%$ of the variance were considered non-significant relationships and are labeled 'ns'.

within seagrass and macroalgae to consume the benthic plants and/or micro-crustaceans contained therein (Randall 1967, Kieckebush et al. 2004). Thus, it is not surprising that these species were best associated with high covers of benthic plant species, high canopy height, and high micro-crustacean density, all of which can indicate a reliable supply of these species' preferred food items. The group of fish consisting of Gerres cinereus, Halichoeres bivittatus, Lactophrys trigonus, Pomacentrus leucostictus, and Stegastes diancaeus represent mainly herbivorous and zoobenthic feeders (Randall 1967). These species demonstrated preferences for high covers of algal species Batophora oerstedii and Laurencia intricata, which can not only serve as direct food sources for herbivores, but have also been determined to influence the abundance and occurrences of benthic microcrustaceans (Nero \& Sealey, unpublished data) available to zoobenthic feeders. The group of fishes consisting of Abudefduf saxtalis, Albula vulpes, Bothus ocellatus, Carangoides bartholomaei, Eucinostomus melanopterus, Sphyraena barracuda, Strongylura notata, and Trinectes inscriptus represents a mixture of invertebrate feeders and piscivores (Randall 1967). Their observed inclination for habitats with low cover of erect benthic flora may result in increased zoobenthic foraging success and predation efficiency due to increased bare sand and reduced refuge availability for potential prey items. For example, bonefish, Albula vulpes, are particularly well-noted for their tendencies to forage for invertebrate prey in bare sand areas (Colton \& Alevizon 1983). Lastly, the group consisting of Caranx latus, Eucinostomus lefroyi, Harengula humeralis, Polydactylus oligodon, Trachinotus falcatus, Trachinotus goodei, and Umbrina coroides represent sand-foraging invertebrate feeders and omnivorous predators (Randall 1967, Silvano 2001). Thus, their habitat 
preferences for areas with high micro-crustacean diversity, high turf cover, and low cover of erect seagrasses and macroalgae also likely enable high success of foraging in the sand and spotting and capturing prey items. The recurring observation that species with similar feeding habits preferred habitats which seem most consistent with optimizing foraging success supports the idea that fish community patterns are not random, but are connected to environmental patterns. Such findings also further support the notion that fish distributions can be accurately predicted if detailed knowledge of the environment and local recruitment variability is accessible.

We thus conclude that fish species patterns are linked to environmental patterns. Although the environmental variables we addressed only explained $50.19 \%$ of the variation in fish species patterns, these results still contribute to a better understanding of fish-habitat relationships, as an ordination diagram with even a low percentage of variation explained by the environmental variables can nevertheless provide valuable information (Ter Braak 1986). Furthermore, being able to explain $100 \%$ of the variability is highly unlikely, especially since part of the total variance is due to noise in the dataset (Ter Braak 1986). One should also consider the inherently large variability in coastal fish patterns (see Nero \& Sealey 2005, Nero \& Sealey in press). Thus, the variables included in this study appear to be important determinants of fish distribution patterns, even though other variables not examined in this study may also be of importance in influencing fish species distributions. The apparent differences in the spatial clustering patterns of samples based upon environmental variables (Figure 1) and the temporal clustering patterns of samples based upon fish species patterns (Figure 2) also suggest that other variables, such as turbidity and/or salinity, may also influence fish settlement and activity patterns. Inter-specific interactions among the various fish species may also influence a given sample's composition. Lastly, since near-shore habitats are commonly occupied by young recruits of coral reef fishes (Mateo and Tobias 2001) which rely at least partially on oceanographic influences to transport them relatively long distances to settlement sites (Underwood \& Keough 2001), larger-scale oceanographic processes, such as regional storm events and currents (Hovel et al. 2002), and species-specific reproductive and recruitment patterns may also contribute to observed fish distribution patterns.

An underlying objective of this study was to better understand the relationships between anthropogenic activity on the coastline and coastal fish community structure. DCCA highlighted the extent of exotic plants as the second most important environmental characteristic influencing fish communities, thereby indicating that fish species may respond to terrestrial activities that alter nutrient and sediment regimes. However, that the other anthropogenic factor, extent of destructive land use, was not retained by the DCCA, suggests a contradictory view that fish community patterns may not respond to anthropogenic-induced changes to sediment and nutrient regimes, or at least not at a degree detectable by this analysis. One must consider that while the extent of exotic invasive plants represents a real-time measurement (the extent of exotic plants present at the time of survey), the extent of destructive land-use represents historical activity (based upon evidence of sand-mining and/or garbage dumping present, with no information regarding when the anthropogenic activity actually occurred). Thus, in the case of destructive land use, we cannot rule out the possibility that sample sites may have been historically exposed to destructive activities, but such activities have stopped and allowed for ecosystem recovery (Sousa 2001), and a return to system equilibrium. Thus, our examination of the effects of destructive land-use patterns on fish communities is limited in its time resolution and presents a simplified view of these specific anthropogenic effects.

Studies that monitor time-series responses of fish communities beginning at the initiation of the anthropogenic activity may better elucidate direct relationships between anthropogenic activity and coastal fish patterns. Although difficult, simultaneously completing anthropogenic activity assessment, direct measurements of sediment and nutrients, and fish community characterizations can also improve our understanding of the complex inter-relationships between anthropogenic activities, water quality, and fish community patterns. Alternatively, it should be acknowledged that recruitment variability may be of more 
importance than anthropogenic activity in determining the distribution and abundance of fishes. If recruitment variability is the overriding influence, minimal responses to anthropogenic variables may be expected.

Our results, when combined with conclusions of other studies, indicate that anthropogenic activities can also indirectly affect coastal fish community composition. Because our study clearly illustrates the importance of benthic floral patterns in determining the distributions and abundances of different fish species, we must also consider the effects that anthropogenic activity can have on benthic flora. Human activity on the coast, including the two types of activity that we investigated, can change the concentration, composition, and/or pulsing frequency of nutrients and sediments from land to sea (Sealey et al. 2004), which can elicit observable responses, such as changes in diversity or abundance, of seagrasses and macroalgae (Borowitzka 1972, Herrnkind et al. 1988, Lapointe et al. 1994, Morand \& Briand 1996, Lapointe 1997, Umar et al. 1998, McCook 1999, Smith et al. 2001, Diaz et al. 2002). Because our study indicated that fish are responsive to benthic flora composition, human-induced changes in the benthic flora (and, therefore, habitat quality) may likely result in subsequent changes in the fish community. Thus, we infer that human activities that alter natural nutrient and sediment regimes may not only elicit direct responses from fishes, but may also indirectly influence fishes by shaping benthic plant assemblage composition. The direct and immediate effects of human activity on benthic flora can, ultimately, determine habitat quality for fishes, and thus have consequences on community dynamics and secondary production of fishes in coastal waters.

The results and conclusions of this work have conservation-based implications. To effectively protect a species, it is necessary to protect its habitat (Siitonen \& Saaristo 2000, Sergio et al. 2003), and our work provides information regarding the juvenile habitat preferences of many fish species which will, as adults, occupy coral reefs. To maintain the high diversity of species on coral reefs (Connell 1978), it is also necessary to protect the habitats used prior to ontogenetic shifts to reef habitats. Thus, our work can help conservation biologists identify specific sites that can provide necessary habitat requirements, and thus be managed with respect to natural and anthropogenic activities.

\section{Conclusion}

In conclusion, we determined that fish community composition is related to a variety of environmental characteristics, with benthic flora canopy height, extent of invasion by exotic plants, cover of Batophora oerstedii, cover of Thalassia testudinum, sea surface temperature, micro-crustacean diversity, and micro-crustacean density being most strongly related to fish patterns. Many fish species demonstrated similarities in their spatial distributions, which are most likely explained by shared trophic habits and preferences for habitats that maximize foraging success. The extent of exotic invasive plants may elicit responses of fish by altering sediment and nutrient regimes. The influence of benthic flora patterns on fish communities also suggests that anthropogenic-induced alterations to benthic plants can have secondary effects on coastal fish communities.

\section{Acknowledgements}

This work was supported by the Earthwatch Institute's Coastal Ecology of the Bahamas Expedition, Sigma Xi Grants in Aid of Research, and an appointment to the NOAA EPP MSI Graduate Sciences Program administered by the Oak Ridge Institute for Science and Education through an interagency agreement between the U.S. Department of Energy and the U.S. Department of Commerce. We thank K. Semon, A. Potts, D. SanFilippo, M. Blackwell, C. Brennan, C. Bain and all of the Earthwatch volunteers who helped with the beach seining. We appreciate the insightful and useful comments of the anonymous reviewers, who helped improved this manuscript. 


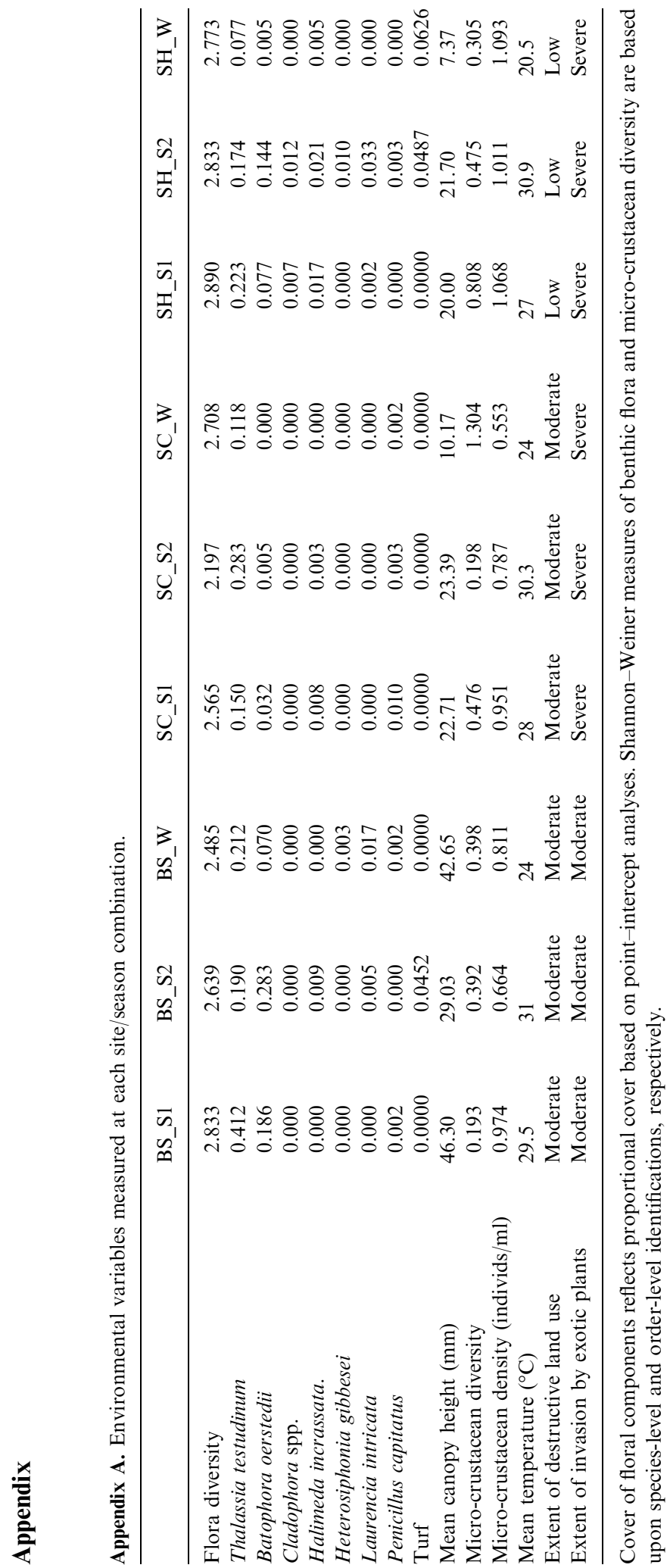




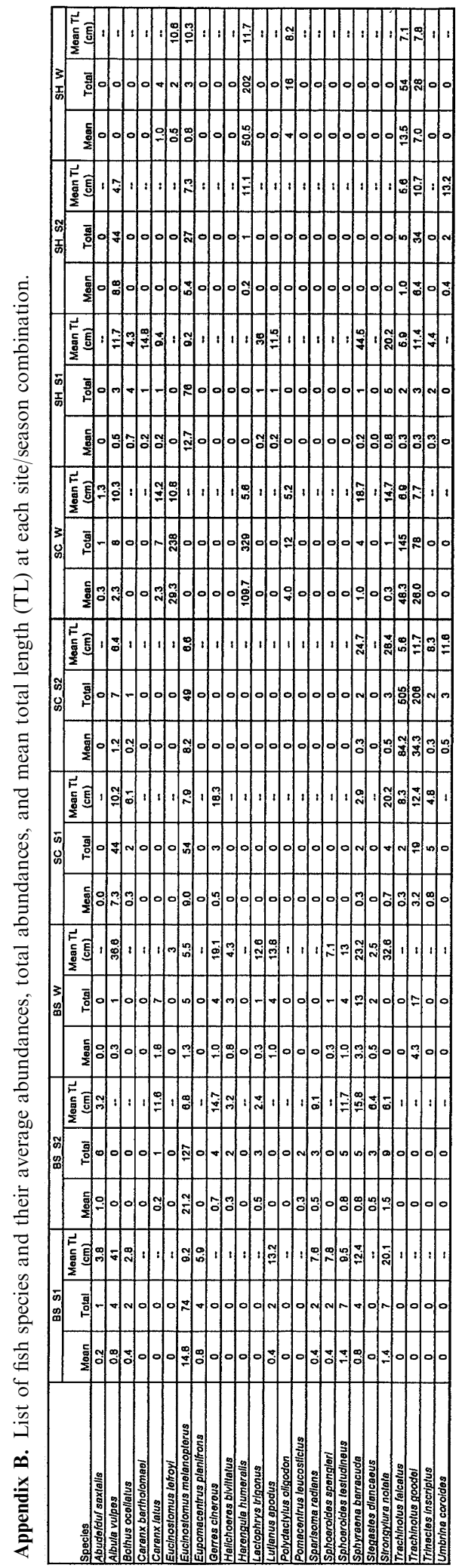

\section{References}

Able, K., M.P. Fahay, K.L. Heck Jr., C.T. Roman, M.A. Lazzari \& S.C. Kaiser. 2002. Seasonal distribution and abundance of fishes and crustaceans in a Cape Cod Estuary. North East. Nat. 9: 285-302.

Allee, R.J., M. Dethier, D. Brown, L. Deegan, R.G. Ford, T.F. Hourigan, J. Maragos, C. Schoch, K. Sealey, R. Twilley, M.P. Weinstein \& M. Yoklavich. 2000. Marine and Estuarine Ecosystem and Habitat Classification. NOAA Technical Memorandum NMFS-F/SPO-43.

Azevedo Bemvenuti, M. 1990. Feeding habits of the silversides (Atherinidae) in the estuary of Patos Lagoon RS, Brazil. Atlantica 12(1):79-102.

Borowitzka, M. 1972. Intertidal algal species diversity and the effect of pollution. Aust. J. Mar. Freshw. Resour. 23: 73-84.

Chittaro, P. 2004. Fish-habitat associations across multiple spatial scales. Coral Reefs 23: 235-244.

Clark, J.R. 1998. Coastal Seas: The Conservation Challenge. Blackwell Science, Oxford. 134 pp.

Colton, D.E. \& W.A. Alevizon. 1983. Movement patterns of Bonefish, Albula vulpes, in Bahamian waters. Fish. Bull. 81(1):148-154.

Connell, J. 1978. Diversity in tropical rainforests and coral reefs. Science 199: 1302-1310.

Crowder, L. \& W.E. Cooper. 1982. Habitat structural complexity and the interaction between bluegills and their prey. Ecology 63: 182-1813.

DeLeon, S. 1999. Atherindiae of San Francisco Bay. In: Report on the 1980-1995 fish, shrimp, and crab sampling in the San Francisco estuary, California. pp. 217-248.

Diaz, P., J.J. Lopez \& M.L. Piriz. 2002. Symptoms of eutrophication in intertidal macrolgal assemblages of Nuevo Gulf (Patagonia, Argentina). Botanica Marina 45: 267-273.

Eggleston, D.B. 1995. Recruitment in Nassau grouper Epinephelus striatus: Post-settlement abundance, microhabitat features, and ontogenetic habitat shifts. Mar. Ecol. Prog. Ser. 124: 9-22.

Gore, R., E.A. Gallaher, L.E. Scotto \& K.A. Wilson. 1981. Studies on decapod crustacea from the Indian River Region of Florida. Estuar. Coast. Shelf Sci. 12: 485-508.

Grigg, R.W. 1994. Effects of sewage discharge, fishing pressure, and habitat complexity on coral ecosystems and reef fishes in Hawaii. Mar. Ecol. Prog. Ser. 103: 25-34.

Guidetti, P., G. Fanelli, S. Fraschetti, A. Terlizzi \& F. Boero. 2002. Coastal fish indicate human-induced changes in the Mediterranean littoral. Mar. Environ. Res. 53: 77-94.

Hammerton, J. 2001. Casuarinas in the Bahamas: A clear and present danger. Bahamas J. Sci. 9: 2-14.

Helfman, G.S., B.B. Collette \& D.E. Facey. 1997. The Diversity of Fishes. Blackwell Science, Malden, MA. 528 pp.

Herrnkind, W., M. J. Butler IV \& R.A. Tankersley. 1988. The effects of siltation on recruitment of spiny lobsters, Panuliru argus. Fish. Bull. 86: 331-338.

Hovel, K., M.S. Fonseca, D.L. Meyer, W.J. Kenworthy \& P.E. Whitfield. 2002. Effects of seagrass landscape structure, structural complexity and hydrodynamic regime on macrofaunal densities in North Carolina seagrass beds. Mar. Ecol. Prog. Ser. 243: 11-24. 
Huston, M. 1979. A general hypothesis of species diversity. Am. Nat. 113: 81-101.

Hyndes, G., A.J. Kendrick, L.D. MacArthur \& E. Stewart. 2003. Differences in the species- and size-composition of fish assemblages in three distinct seagrass habitats with differing plant and meadow structure. Mar. Biol. 142: 1195-1206.

Kieckbusch, D., M.S. Koch, J.E. Serafy \& W.T. Anderson. 2004. Trophic linkages among primary producers and consumers in fringing mangroves of subtropical lagoons. Bull. Mar. Sci. 74: 271-285.

Kohn, A. \& P.J. Leviten. 1976. Effect of habitat complexity on population density and species richness in tropical intertidal predatory gastropod assemblages. Oecologia 25: 199-210.

Lapointe, B. 1997. Nutrient thresholds for bottom-up control of macroalgal blooms on coral reefs in Jamaica and southeast Florida. Limnol. Oceanogr. 42: 1119-1131.

Lapointe, B., D.A. Tomasko \& W.R. Matzie. 1994. Eutrophication and trophic state classification of seagrass communities in the Florida Keys. Bull. Mar. Sci. 54: 696-717.

Layman, C., D.A. Arrington, R.B. Langerhans \& B.R. Silliman. 2004. Degree of fragmentation affects fish assemblage structure in Andros Island (Bahamas) Estuaries. Carib. J. Sci. 40: $232-244$.

Lewis, J.A. 1983. Floristic composition and periodicity of subtidal algae on an artificial structure in Port Phillip Bay (Victoria, Australia). Aquat. Bot. 15(3): 257-274.

Marx, J. \& W.F. Herrnkind. 1985. Macroalgae (Rhodophyta: Laurencia spp.) as habitat for young juvenile spiny lobsters, Panulirus argus. Bull. Mar. Sci. 36: 423-431.

Mateo, I. \& W.J. Tobias. 2001. The role of nearshore habitats as nursery grounds for juvenile fishes on the northeast coast of St. Croix, USVI. Proc. Gulf Carib. Fish. Inst. 52: 512-530.

McClanahan, T., K. Bergman, M. Huitric, M. McField, T. Elfwing, M. Nystrom \& I. Nordemar. 2000. Response of fishes to algae reduction on Glovers Reef, Belize. Mar. Ecol. Prog. Ser. 206: 273-282.

McCook, L. 1999. Macroalgae, nutrients, and phase shifts on coral reefs: Scientific issues and management consequences on the Great Barrier Reef. Coral Reefs 18: 357-367.

Morand, P. \& X. Briand. 1996. Excessive growth of macroalgae: A symptom of environment disturbance. Botanica Marina 39: 491-516.

Myers, A. \& T. Southgate. 1980. Artificial substrates as a means of monitoring rocky shore cryptofauna. J. Mar. Biol. Assoc. U.K 60: 963-975.

Nagelkerken, I. \& G. Velde. 2004. Relative importance of interlinked mangroves and seagrass beds as feeding habitats for juvenile reef fish on a Caribbean island. Mar. Ecol. Prog. Ser. 274: 153-159.

Nero, V.L. \& K.S. Sealey. 2005. Characterization of tropical near shore fish assemblages by coastal habitat status on spatially complex island systems. Environ. Biol. Fish 73: 437444.

Nero, V.L. \& K.S. Sealey. In press. Univariate and multivariate assessment of the relationships between macroalgae/seagrass assemblages and fish assemblages in coastal marine habitats of The Bahamas. Proceedings of the 57th Gulf and Caribbean Fisheries Institute.
Polis, G. \& S.D. Hurd. 1996. Linking marine and terrestrial food webs: Allochthonous input from the ocean supports high secondary productivity on small islands and coastal land communities. Am. Nat. 147: 396-423.

Randall, J. 1967. Food habits of reef fishes of the West Indies. Stud. Trop. Oceanogr. 5: 665-847.

Roberts, C. \& R.F.G. Ormond. 1987. Habitat complexity and coral reef fish diversity and abundance on Red Sea fringing reefs. Mar. Ecol. Prog. Ser. 41: 1-8.

Rotherham, D. \& R.J. West. 2002. Do different seagrass species support distinct fish communities in south-eastern Australia? Fish. Manage. Ecol. 9: 235-248.

Sanchez, I., C. Fernandez \& J.M. Rico. 2003. Distribution, abundance, and phenology of two species of Liagora (Nemaliales, Rhodophyta) in northern Spain. Phycologia 42(1): $7-17$.

Sealey, K., A.L. Flowers, V.L. Nero, K.L. Semon \& J. Wilson. 2004. Characterization and ranking of coastal environments of the Bahamian Archipelago: A database for protection and policy. Bahamas J. Sci. 10: 12-25.

Sergio, F., P. Padrini \& L. Marchesi. 2003. Reconciling the dichotomy between single species and ecosystem conservation: Black kites (Milvus migrans) and eutrophication in preAlpine lakes. Biol. Conserv. 110(1): 101-111.

Siitonen, J. \& L. Saaristo. 2000. Habitat requirements and conservation of Pytho kolwensis, a beetle species of oldgrowth boreal forest. Biol. Conserv. 94(2): 211-220.

Silvano, R. 2001. Feeding habits and interspecific feeding associations of Caranx latus (Carangidae) in a subtropical reef. Environ. Biol. Fish. 60: 465-470.

Smith, J., C.M. Smith \& C.L. Hunter. 2001. An experimental analysis of the effects of herbivory and nutrient enrichment on benthic community dynamics on a Hawaiian reef. Coral Reefs 19: 332-342.

Sousa, W. 2001. Natural disturbance and the dynamics of marine benthic communities. pp. 85-130. In: M. Bertness, S.D. Gaines \& M.E. Hay, (eds.), Marine Community Ecology, Sinauer Associates, Inc, Sunderland, MA.

Tabachnick, B. \& L. Fidell. 1996. Using Multivariate Statistics. 3 ed.Harpercollins, New York..

Ter Braak, C. 1986. Canonical correspondence analysis: A new eigenvector technique for multivariate direct gradient analysis. Ecology 67: 1167-1179.

Umar, M., L.F. McCook \& I.R. Price. 1998. Effects of sediment deposition on the seaweed Sargassum on a fringing coral reef. Coral Reefs 17: 169-177.

Underwood, A.J. \& P. Jernakoff. 1984. The effects of tidal height, wave-exposure, seasonality and rock-pools on grazing and the distribution of intertidal macroalgae in New South Wales. J. Exp. Mar. Biol. Ecol. 75(1): 71-96.

Underwood, A.J. \& M.J. Keough. 2001. Supply-side ecology: The nature and consequences of variations in recruitment of intertidal organisms. pp. 183-200. In: M. Bertness, S.D. Gaines \& M.E. Hay, (eds.), Marine Community Ecology, Sinauer Associates, Inc, Sunderland, MA. 